\title{
IS DISTANCE A GOOD PROXY FOR TRANSPORT COSTS?: THE CASE OF COMPETING TRANSPORT MODES
}

\author{
Inmaculada Martínez-Zarzoso* \\ Felicitas Nowak-Lehmann D. **
}

\begin{abstract}
In this paper, we analyze separately the determinants of maritime transport and road transport costs for Spanish exports to Poland and Turkey (markets for which maritime and road transport are competing modes) and investigate the different effects of these costs on international trade. First, we investigate the extent to which maritime and road transport costs depend on different factors such as unit values, distances, transport conditions, service structures, and service quality. Second, we analyze the relative importance of road and maritime transport costs in comparison with distance measures as determinants of trade flows. The main results of this investigation indicate that real distance is not a good proxy for transportation costs and identify the central variables influencing road and maritime transportation costs: for both modes, transport conditions are strong determinants, whereas efficiency and service quality are more important for maritime transport costs, and geographical distance is more important for road transport. Road and maritime transport costs are central explanatory factors of exports and they seem to deter trade to a greater extent than road or maritime transit time when endogeneity is considered.
\end{abstract}

Keywords: transport costs, transport mode, Spanish exports, international trade

JEL classification: $\mathrm{F} 1, \mathrm{O} 1, \mathrm{O} 55$

\footnotetext{
Universidad Jaume I, Castellón, Spain and Ibero-America Institute for Economic Research Universität Göttigen, Germany. Financial support from Fundación Caja Castellón-Bancaja, Generalitat Valenciana and the Spanish Ministry of Education is grateful acknowledged (P1-1B2005-33, Grupos 03-151, INTECO; Research Projects GV04B-030, SEJ 2005-01163 and ACOMP06/047). Corresponding author: Ibero America Institute for Economic Research, Universität Göttingen, 37077 Göttingen, Germany. E-mail: martinei@eco.uji.es. Tel: 0049551399770. We would like to thank the participants of the Work-shop in International Economics hold at the University of Goettingen in March 2006 for their helpful comments and suggestions.

** Ibero-America Institute for Economic Research and Center for Globalization and Europeanization of the Economy, Universität Göttigen, Germany.
} 


\section{IS DISTANCE A GOOD PROXY FOR TRANSPORT COSTS?: THE CASE OF COMPETING TRANSPORT MODES}

\section{INTRODUCTION}

The recent literature has shown a growing interest in studying the role of trade costs in models of international trade. Krugman's (1991) seminal work in economic geography models emphasizes the crucial importance of trade costs. Recent studies have confirmed the significant impact of trade costs, not only for international trade levels but also for the structure of economic activities (Radelet and Sachs, 1998).

The main components of trade costs are international policy barriers (both tariff and nontariff), transportation costs (freight and time), and distribution costs. In a recent study, Anderson and van Wincoop wrote that, "trade costs are large, even aside from trade-policy barriers and even between apparently highly integrated economies."

In the world economy today, where the globalization of trade is closely associated with the fragmentation of production among different countries, transportation costs are of central importance. The regionalism movements of the 1960s and 1990s played an important role in this globalization process, the latter of which has led to such large trading blocs as the European Union, NAFTA and MERCOSUR. These regional integration agreements have brought about an expansion of trade, a general reduction of tariff rates, and the adoption of outward-oriented strategies by many developing countries. As a consequence, international transportation has attained even greater importance, and may now rightly be considered one of the pillars of the global economy.

A number of authors have recently investigated the determinants of transport costs from an empirical point of view (Limao and Venables, 2001; Mico and Pérez, 2002; Clark, Dollar and Mico, 2004; Egger, 2004; Combes and Lafourcade, 2005; Martinez-Zarzoso and SuárezBurguet, 2005). These studies show that geographic conditions, the type of product transported, economies of scale, energy prices, trade imbalances, infrastructures, transport mode, competition and regulations are among the most important factors explaining the variation in transport costs across countries. An important finding of these studies is that a $10 \%$ reduction in transport costs increases trade volumes by more than $20 \%$. However, the difficulties involved in measuring and inferring the value of transport costs, together with their high variability across goods, countries, and regions, calls for further investigation.

\footnotetext{
${ }^{1}$ Anderson and van Wincoop (2004), p. 691.
} 
Transportation costs may reflect the costs directly involved in shipping (cost of service) or may be determined by the value of the commodity (value of service). Yet little attention has been given to the role of service quality and travel time as determinants of transport costs, due largely to the lack of relevant data and the difficulty of measurement. Another widely neglected aspect is the importance of transportation costs for different modes of transport. Within the European market, this may be particularly important where road and maritime transport (short sea shipping) compete with each another for some destinations.

In this paper, we aim to fill these research gaps. We undertake a comparative analysis of the transport cost and trade structures between two different destinations for Spanish exports: Poland and Turkey. Poland has been a member of the European Union since 2004, while Turkey, in preparation for accession, signed an incomplete Custom Union Agreement with the EU-15 in 1996 and has also concluded free trade agreements with the majority of countries that joined the EU in the most recent round of enlargement, Poland included. Our selection of these two countries was based on several criteria. First, in both Poland and Turkey, there is competition between maritime and road transport modes for Spanish exports ${ }^{2}$. Second, they have similar levels of road and port infrastructure development. Third, since both countries have signed trade agreements with the EU, protection is nonexistent or very low for many commodities (industrial products), apart from agricultural products in Turkey. For all of these reasons, transport costs should be a key element for the competitiveness of Spanish exports in both markets, and the comparative analysis can offer useful insights.

Turkey is also of particular interest because of its geopolitical position as a link between the East and the West, making the transport sector a key element for the region's economic development. Turkey plays an important role not only as a transit country but also as an origin and destination of freight. The recent developments in the EU accession process ${ }^{3}$ and the country's growing role in trade between Central Asia and the South Caucasus increase the importance of transport costs as a key determinant of trade flows.

The paper is organized as follows. In the next section, we discuss the main determinants of transport costs, and in Section 3, we present our model specification and the data and variables used. In Section 4, we discuss our main findings. In Section 5, we analyze the sensitivity of the results, and Section 6 concludes.

\section{MODEL SPECIFICATION, DATA DESCRIPTION AND DEFINITION OF VARIABLES}

\footnotetext{
${ }^{2}$ Air transport is not considered as a substitute for land or water transport because less than $3 \%$ of the shipments are transported by air.

${ }^{3}$ Formal negotiations started in October 2005.
} 


\subsection{Model Specification}

From a theoretical point of view, a general formulation of transport costs for commodity $\mathrm{k}$ shipped between countries $\mathrm{i}$ and $\mathrm{j}$, in a given period of time, can be written as:

$\mathrm{TC}_{\mathrm{ijk}}=\mathrm{F}\left(\mathrm{X}_{\mathrm{i}}, \mathrm{X}_{\mathrm{j}}, \mathrm{V}_{\mathrm{ij}}, \mathrm{Y}_{\mathrm{ijk}}, \mu_{\mathrm{k}}, \eta_{\mathrm{ijk}}\right)$

where $X_{i}$ and $X_{j}$ are origin and destination-specific characteristics, $V_{i j}$ is a vector of characteristics relating to the journey between $\mathrm{i}$ and $\mathrm{j}, \mathrm{Y}_{\mathrm{ijk}}$ a vector of characteristics depending on the country of origin and destination and the type of product $(\mathrm{k}), \mu_{\mathrm{k}}$ is a product-specific effect that captures differences in transport demand elasticity across goods, and $\eta_{\mathrm{ijk}}$ represents unobservable variables.

The country characteristics, $X_{i}$ and $X_{j}$, usually incorporate geographical and infrastructural measures. Typically, dummy variables are used to control for a country that is either landlocked or an island. Quality of service, distance between origin and destination, and volume of imports transported via a particular route, proxied by the volume of imports between countries $i$ and $j$, are variables included in vector $V_{i j}$. Among the characteristics that also depend on the type of product, $Y_{i j k}$, we focus on the transport conditions required and the unit-to-weight value for product $k$ transported from country $i$ to country $j$. Product-specific dummy variables are also modeled to account for $\mu_{k}$.

Assuming a multiplicative form, a transport cost function can be written as:

$$
t c_{i j k}=i v u_{i j k}^{\alpha_{1}} x v o l_{i j k}^{\alpha_{2}} \operatorname{dist}_{i j}^{\alpha_{3}} \operatorname{lin}_{i j}^{\alpha_{4}} \text { quality }_{i j}^{\alpha_{5}} e^{\beta_{1} c o n s+\beta_{2} r e f r i+\beta_{3} \text { country }+\beta_{4} \bmod e+\mu_{k}+\eta_{i j k}}
$$

where $t c_{i j k}$ denotes freight in $€$ per tonne, $i$ the province of origin in Spain, $j$ the destination country and the specific shipment of product $k$. ivu $\mathrm{ijk}_{i j}$ denotes the value-to-weight ratio (unit value: $€$ per $\mathrm{Kg}$ ), $\mathrm{x} v o l_{i j k}$ is the volume of exports of shipment $k$ between $i$ and $j$, dist ${ }_{i j}$ denotes distance between the province of origin and the port (maritime transport) or commercial centre (road transport) of destination, $\operatorname{lin}_{\mathrm{ij}}$ denotes the degree of competition between lines proxied by the number of lines operating on a route, quality denotes the quality of the service (frequency, number of scales, containerization and time). Cons and refri are dummies that denote consolidated and refrigerated shipments, country and mode are dummies for the destination country and for the transportation mode. Country takes the value one when a product is exported to Turkey and zero when a product is exported to Poland and mode takes the value one when products are transported by road and zero otherwise, $\mu_{k}$ represents 
product-specific effects, and $\eta_{\mathrm{ijk}}$ denotes the error term, which is assumed to be independently distributed.

We estimate two linear versions of equation (2), one for maritime transport costs and a second for road transport costs. Taking natural logarithms, the general specification is given by,

$$
\begin{aligned}
& \ln t c_{i j k}=\alpha_{0}+\alpha_{1} \ln i v u_{i j k}+\alpha_{2} \ln x_{\text {vol }}+\alpha_{i j k}+\alpha_{3} \ln \text { dist }_{i j}+\alpha_{4} \ln \operatorname{lin}_{i j}+\alpha_{5} \ln \text { freq }_{i j}+\alpha_{6} \ln e \mathrm{sc}_{i j}+ \\
& \alpha_{7} \text { cont }_{i j}+\beta_{1} \text { cons }+\beta_{2} \text { refri }+\beta_{3} \text { country }+\beta_{4} \operatorname{mode}+\mu_{k}+\eta_{i j k}
\end{aligned}
$$

where $\ln$ denotes natural logarithms. Transport service quality is proxied by the connectivity between countries measured as the frequency of the service $\left(\right.$ freq $\left._{i j}\right)$; the number of scales made on the way $\left(e s c_{i j}\right)$ and the percentage of containerized cargo $\left(\right.$ cont $\left._{i j}\right)$. The variables "frequency", number of lines, and number of scales are specific determinants of maritime transport costs. Consequently, they are not considered as determinants of road transport costs. One of the main objectives of estimating the determinants of transportation costs is to look at these findings in relation to international trade and to quantify the impact of transport costs as a "natural" trade barrier. To accomplish this we need an appropriate theoretical framework. We base our application on Hummels' (1999) model, which is derived from the commonly accepted Dixit-Stiglitz model of imperfect competition. According to Hummels' model, bilateral imports depend on the two countries' GDPs, the distances involved and indicators of adjacency, common languages and other geographical characteristics (landlockedness). However, given the specific characteristics of our empirical application, which takes only an exporter country and two importer countries into consideration, the effects of exporter and importer incomes will be included in the constant and the country dummy term respectively. Furthermore, the trade partners do not share borders or language and are not landlocked. Hence, these variables are excluded.

We specify a trade equation in which the trade cost components are related to natural trade barriers such as distance (transport costs) and time. The basic equation is given by:

$$
\ln x v o l_{i j k}=\beta_{0}+\beta_{k}+\beta_{1} \ln t c_{i j k}+\beta_{2} \ln t i m e_{i j k}+\beta_{3} \text { country }+\beta_{4} \bmod e+v_{i j k}
$$

where ln denotes natural logarithms, $i$ is the exporting province in Spain and $j$ the importing country; $t c_{i j k}$ is the variable representing transport costs and time $e_{i j k}$ is real transit time. In a first steep equations (3) and (4) will be estimated by ordinary least squares (OLS). The OLS results are consistent for the transport costs equations, but not for the trade equations since transport costs are found to be endogenous in the latter. However, the OLS results for the trade equation are also shown for comparative purposes. 
In a second step, equations (3) and (4) will be estimated simultaneously by 2SLS and 3SLS in order to consider the possible reverse causation between trade and transport costs identified in other recent studies (Martinez-Zarzoso and Suarez-Burguet, 2005).

\subsection{Data and Sources}

The data on transport costs used in this study were derived from the database TradeTrans Spanish Trade and Transport Flows developed by Fundación Valenciaport. TradeTrans compiles export declaration forms and supplements them with a series of variables providing information about the mode of transport, transport route that each export shipment follows, and the costs and time needed by the particular transport service used for each shipment leaving Spain with destination in 23 countries. Data for each of the 8,425 shipments exported as containerized cargo from the 51 Spanish provinces to Poland and Turkey in 2003 were used in the empirical model. These represent all the Spanish maritime and road shipments to our two destination countries, apart from cases with a large proportion of missing values (these excluded shipments represent only $0.3 \%$ of the total number of cases).

Table 1 shows the structure of the shipments according to the mode of transport. Exports to Poland are mainly transported by road (96\%) whereas exports to Turkey are mainly transported by sea (56\%). The third and eighth columns show the average unit transport costs for road and sea transport for each of the two destinations respectively. Sea transport is cheaper than road transport for both destinations and in general slightly lower for Turkey. Road transport costs are, as expected, higher for exports to Turkey than for exports to Poland since the real road distance is longer to Turkey. However, we see lower ad valorem transport costs for Turkey for both transport modes, the reason being that exports to Turkey have higher value-weight ratios (€/kilo) on average, as shown in columns 5 and 10 . Therefore, for products sent to Turkey the transport costs represent a lower proportion of the total value of the shipment. Finally, with respect to transit time, four and a half days are needed on average to transport a shipment from Spain to Poland, whereas two more days (six and a half) are needed for shipment to Turkey. For maritime transport, the transit time is fourteen days to Turkey and sixteen to Poland.

\section{Table 1. Structure of Spanish Exports to Poland and Turkey}

Trade data are derived from the 2003 COMEXT database (EUROSTAT) using annual data disaggregated at the eight-digit level according to the Combined Nomenclature (Harmonized 
System). This level of disaggregation was chosen in order to match the data on trade with the data on transport costs.

\subsection{Variable Definitions and Expected Signs}

The dependent variable in the model estimated for transport costs (equation (3)) is the freight rate between the region of origin in Spain and the city of destination. This variable expresses the unitary cost in euros per metric ton that the exporter or the importer has to pay for the containerized export shipment to be transported by sea or road. For every pair of port of origin and port of destination, we obtained quotes of ten different freight rates charged for transporting a TEU (twenty equivalent unit container), an FEU (forty equivalent unit container) and a shipment needing refrigeration and/or consolidation. The freight rate is the average of these quotes from at least ten different shipping agents. The agents selected were representative of shipping lines offering these services between each specific port of origin and destination. The weight of the goods transported in each shipment and the ratio metric tons per TEU or FEU, depending on the type of merchandise exported, were taken into account.

The explanatory variables in equation (3) and their a priori expected signs are:

The Index of Unitary Value is defined as the ratio of value/weight (in euros/kilogram) and is calculated for each specific export shipment ${ }^{4}$. The expected sign of this variable as a determinant of maritime transport costs is positive, since the transport insurance will have a stronger effect the higher the value of the specific good.

The variable "volume exported" is the total weight in metric tons of the Spanish export flows shipped in containers to each specific country of destination. An increase in the exported volume can be expected to have a negative impact on transport costs, since a larger volume would generate further economies of scale at the exporter level, therefore reducing the freight rate applied. The relationship between trade and transport costs, however, works both ways, as a decrease in transport costs would also promote an increase in trade. This fact should be considered in the empirical analysis.

As far as distance is concerned, several measures are defined. For sea transport we use the average distance in kilometers between the Spanish province of origin and the port of destination. This variable can be decomposed into land and maritime distance components. The first component measures the land distance traveled in Spain from the province of origin to the port of exit. The second component has been calculated as an average of the real distances traveled by the different lines offering a transport service. The source of this data is

\footnotetext{
${ }^{4}$ It provides a consistent indicator of the value of the exported merchandise.
} 
the Fundación Valenciaport's database Lineport. This database compiles information on every call made at one of five main Spanish ports for the purpose of loading cargo (for those lines published on the port's webpage or in port community journals). Lineport has compiled information on vessel calls to Spanish ports for all lines operating between Spain and Europe since 2003. For road transport we use the real distance ${ }^{5}$ between the province of origin and the commercial center of destination. The expected sign of the distance variables is positive, since the longer the distance traveled, the larger the costs involved and therefore the higher the tariff charged.

The "number of lines" variable is used as a proxy of the degree of competition between lines offering the same maritime transport service at a specific port. An increase in this variable would cause a decrease in transport costs; hence the sign of this variable is expected to be negative. The source of this data is the Fundación Valenciaport's database Lineport. For every observation, the value assigned to this variable is the number of regular maritime lines offering a transport service from the port of origin to the port of destination of the observation considered. All shipping lines that publicize their services between the two ports under study have been included.

The variable frequency is defined as the number of days between service departures, and reports the average time in days between two consecutive calls by vessels used regularly for transporting goods between the port of origin and the port of destination (according to the data published by the different lines). The source for calculation of this variable was the Lineport database. The effect of the number of days between service departures on the average service freight rate can be twofold: on the one hand, frequency can be seen as a proxy for service quality since more frequent port-to-port service decreases the shipper's average door-to-door transit time and increases flexibility in planning shipments. The impact of frequencyperceived as quality-on the freight rate will thus be positive, since a decreased interval between shipments would increase the maritime service price. Conversely, an increased number of days between service departures would decrease the maritime service price. On the other hand, infrequent services between the two ports or an increased number of days between departures from port of origin to port of destination indicate a lack of competition between different shipping lines. In this case, a longer time interval between departures means less competition and increased freight rates. Since the two effects described have opposite impacts on transport costs, the expected sign for this variable is ambiguous and the estimation results may indicate which effect is the dominant one.

\footnotetext{
${ }^{5}$ Actual kilometers of road traveled.
} 
The "number of scales" variable provides information on a shipping line's average number of ports of call between port of origin and port of destination. It is a proxy for service quality and is expected to have a negative sign: a higher number of calls would imply a reduction in service quality and a decrease in the freight rate that the shipping line will be able to charge the shipper.

Commodities that require special conditions for transport, such as refrigerated cargo, would be charged an increased price for transport. A positive sign is therefore expected for the variable "refrigerated cargo". A higher price would be expected for small shipments as well, since in this case a shipping container needs to be filled with cargo from various shippers for delivery to various consignees.

Another variable that influences transport costs is port container traffic. In recent studies, container port traffic (container throughput) has been identified as a useful variable involving economies of scale and port production and efficiency. A more effective terminal can be expected to induce lower unit transport costs, and economies of scale are also seen at the port level, as larger volumes of containerized cargo to be loaded and unloaded will enable the shipping lines to use larger container ships and also permit the terminal operator to optimize the use of terminal equipment, infrastructure and stevedoring shifts. Large port cargo volumes will also tend to attract more liner services, thus increasing the degree of competition between services at that specific port. Raising port container throughput would be likely to imply a reduction in container freight rates. We only have data on the percentage use of containers in a port. This variable was significant and negative when added to the maritime transport cost regressions, but the magnitude of the coefficient was small (-0.001). However, the variable was not included in the final empirical analysis (Poland and Turkey regressions) because it was highly correlated with the variable "number of lines".

\section{EMPIRICAL APPLICATION}

We estimate equation (3) with data for Spanish exports to Poland and Turkey for the year 2003 and for a sample of 8,425 shipments. Separate regressions are run for maritime and road transport. The results are shown in Table 2. Models 1-4 show the results for maritime transport. Model 1 in column 2 shows the estimation results for the baseline model.

\section{Table 2. Determinants of Maritime and Road Transport Costs}

The country dummy (which takes the value one for exports to Turkey) is negative, indicating that a shipment exported to Turkey has a lower maritime transport cost than a shipment exported to Poland. The unit value coefficient is positive and significant at the $1 \%$ level, 
indicating that a higher value of the value-to-weight ratio increases maritime transport costs. The volume exported is a proxy for the presence of economies of scale and shows a significant coefficient with the expected negative sign. Therefore, this result indicates the existence of economies of scale in transport. The real distance (province to destination port) variable also has the expected positive coefficient, indicating that a higher distance is associated with higher transport costs. One alternative way to model the effects of distance on transport costs is to break down total distance into its land and maritime components. When land distance is included in the regressions, the coefficient is significant at the $1 \%$ level and shows the expected positive sign. Model 2 shows that the costs associated with land distance is higher than the costs associated with port-to-port distance. The $\mathrm{R}^{2}$ increased dramatically with the inclusion of land distances in the regression (by 22 percentage points).

Model 3 adds variables related to transportation conditions (consolidated and refrigerated cargo), to the selected transportation mode and to the quality of service (number of lines, frequency, and percentage of containerized cargo). Since the real distance from port to port is highly correlated with the number of scales $(r=0.89)$ the former variable is not included in this model. The goodness of fit increases by 10 percentage points with respect to Model 2 and the additional variables have the expected sign and are significant at the $1 \%$ level. The mode variable (takes the value one when the selected mode is road) indicates that when the selected mode is road, maritime transport costs are higher when the rest of the variables are held constant. Transport conditions are important determinants of maritime transport costs. Consolidated and refrigerated shipments increase transport costs by $9.4 \%$ and $47 \%$ respectively. The quality of service is also important: a $1 \%$ decrease in the number of scales during the trip (higher quality of service) increases transport costs by $0.03 \%$. Also a reduction in the number of days between service departures (better service) increases transport costs and a $10 \%$ increase in containerization reduces transport costs by $0.01 \%$. The coefficient of the variable "number of lines" is negative, pointing towards the hypothesis that this variable is a proxy for competition between lines, since a higher number of lines on a particular route reduce transport costs.

In Model 4, the effect of transit time is evaluated. Initially the coefficient was non-significant and negative. However, since this variable is highly correlated with the number of scales and number of lines, we estimated the model without these two variables. In this case, the transit time variable shows the expected positive coefficient (0.06) and is significant at the 5\% level. However, Model 3 presents a better goodness of fit in terms of the adjusted $\mathrm{R}^{2}$ and the Ramsey test. 
Models 5-8 in Table 4 show the estimation results for road transport. In Model 5, the unit value and volume exported present similar coefficients for maritime and road transport, whereas the distance variable (distance from the province of origin in Spain to the commercial destination site) shows a higher coefficient for road transport than for maritime transport. We observed that the country dummy takes the opposite sign, indicating that shipments to Turkey have higher road transport costs than those to Poland, holding the other explanatory variables constant.

The results of Model 6 indicate that distance and road transport show an inverted U-shaped relationship. However, when transport conditions are added to Model 7, the distance variables are not significant and the volume exported coefficient shows an unexpected positive sign. Since consolidation is related to lower volumes per shipment, we calculate the correlation coefficient between the consolidation dummy and the exported volume variable to check whether there is a problem related to high collinearity between them. The correlation coefficient is very high (-0.78) and we opted to drop the consolidation dummy and instead add an interaction variable (lxvol*cons) that is less correlated with lxvol. The results in Model 8, where transit time and distance are also added, show the expected negative sign for the lxvol variable and a significant coefficient for the transit time, higher in magnitude than the coefficient shown in the maritime transport equation. The transport mode dummy was not significant and was therefore dropped. The goodness of fit in Models 5-8 (0.52-0.80) is clearly better than that in Models 1-4 (0.24-0.57), indicating that we can explain more of the variability in road transport costs than the variability in maritime transport costs. The Ramsey specification test shows that Model 8 is correctly specified.

We also calculated the standardized $B$ coefficients to evaluate the importance of different factors influencing transport costs ${ }^{6}$. The results indicate that transport conditions are the most important determinant for both modes, whereas quality of service is also very important for maritime transport, and transit time is also very important for road transport.

Table 3 shows the results of the trade equations. The traditional variables included in gravity equations (incomes, populations) are not considered in this case since the effect of the exporting country income and population is captured by the constant term, and the differential impact of the income and population in the importing country is captured by the country dummy. We focus on the direct effects of road and maritime transport costs and transit time on exports, and Model 1 shows the estimated coefficients for these variables.

\section{Table 3. Trade Equation Results}

\footnotetext{
${ }^{6}$ The $\beta$ coefficients are not shown in order to save space, but are available upon request.
} 
We observe a higher influence of road transport cost on exports, and even when distance and selected mode of transport are added to the equations, transport costs are significant and carry the expected negative signs. Real distance (port to port) is not significant for maritime transport when transport costs are considered, but road distance (province to commercial center) is significant and negative as expected. However, the magnitude of the estimated coefficient for road distance is much smaller (0.30) than the one corresponding to road transport costs $(-1.70)$ Therefore, distance is not a good proxy for transport costs. Transit times are also important, as indicated by Model 5. The coefficients for road transport costs and transit time are significant and negative, but the coefficients for maritime transport costs and transit times are insignificant and the latter is positive. The country dummy has a high coefficient, and according to the standardized $B$ coefficients, this variable is the most important determinant of export volumes.

There are two possible reasons for these unexpected outcomes. First, equations 3 and 4 were estimated using OLS, but as mentioned above, the relationship between transport costs and trade may operate in both directions. Hence, we should control for the endogeneity of the right-hand variables in the trade and transport cost equations. This can be done by applying two-stage least squares (2SLS) to control for endogeneity ${ }^{7}$ and also three-stage least squares (3SLS) to control for correlated disturbances between the transport costs and the trade equations. Table 4 shows the results of the 3SLS estimation.

\section{Table 4. Determinants of Transport Costs and Trade. System of Equations (3SLS)}

Another reason for the unexpected results previously discussed is that we have two modes of transport and two destination markets. Our objective is to investigate whether there is heterogeneity in the slope coefficients, which can be done by running different regressions for each mode-market combination. We estimate separate equations for Turkey and Poland and for road and maritime transport costs. Table 5 shows the results for Turkey, and Table 6 those for Poland.

The results presented in the first part of Table 4 show that in the trade equation, both maritime and road transport costs present significant estimated coefficients with the expected negative sign. The same is true for both transit-time variables. Exports appear to be more sensitive to

\footnotetext{
${ }^{7}$ We performed the Durbin-Wu-Hausman endogeneity test (Table 4), the null hypothesis of which states that an ordinary least squares (OLS) estimator of the same equation would yield consistent estimates: that is, any endogeneity among the regressors would not have deleterious effects on OLS estimates. A rejection of the null indicates that endogenous regressors' effects on the estimates are meaningful, and instrumental variables techniques are required. The test was first proposed by Durbin (1954) and separately by Wu (1973) (his T4 statistic) and Hausman (1978). The results indicate that the null hypothesis is rejected for the transport cost variables in the trade equation. For the trade volume variables in the transport costs equations, the test could not be performed since the required covariance matrix was not positive definite. However, the differences in the coefficients (OLS versus 3SLS) are very small and therefore the causality runs only from transport costs to trade.
} 
cost components than to time components. The two transport cost equations present similar results to those obtained by OLS. In a further steep, separate regressions are run for each country/transport mode to improve the precision of the estimates.

Table 5 shows the estimation results for the determinants of transport costs for Spanish exports to Turkey; the first part of the table shows the results for the trade equation, the second part for road transport costs and the third part for maritime transport costs. The unit values present a higher coefficient for maritime transport than for road transport in Turkey and the coefficients of the volume exported are similar to those obtained in Tables 2 and 4 (for both destinations).

Table 5. Determinants of Transport Costs and Trade: Turkish Market (3SLS)

Since the variables number of lines and frequency of departures are highly correlated for exports to Turkey (cor=0.91), we opted to include only the number of lines (proxy for the degree of competition in the market). For this variable we obtain the expected negative sign, which is significant at the $1 \%$ level. This indicates that for exports to Turkey, the competition between lines reduces transport costs. This is also the case for Poland (Table 6). The refrigerated cargo dummy presents a much higher coefficient for Turkey's maritime imports than for Poland's maritime imports (the magnitude of the coefficient for Turkey is twice the coefficient for Poland) and is significant in both cases, whereas for road transport costs the opposite is true.

\section{Table 6. Determinants of Transport Costs and Trade: Polish Market (3SLS)}

For Poland's imports, maritime transport costs are determined by transport conditions and the frequency of departures, whereas for Turkey's imports, the main determinants are transport conditions, number of lines, and number of scales.

As far as road transport determinants are concerned, the consolidation dummy is highly correlated with the exported volume for both destinations and therefore the interaction dummy described above is used to overcome the problem. The presence of economies of scale is more evident in the Turkish market since the coefficient of the exported volume is higher, and the distance variable also shows a slightly higher coefficient for Turkey. The differences concerning the rest of variables are not highly pronounced.

Tables 5 and 6 also show the estimation results for the importance of transport costs as determinants of trade for the two destination markets, Turkey and Poland, respectively. 
The estimates for Turkey indicate that maritime transport costs have a larger and significant effect on exports when the presence of endogeneity is taken into account, whereas maritime transit time is not significant. Road transport cost elasticities are higher than road transit time elasticities and both show the expected negative sign. The estimates for Poland present a different picture since both maritime transport costs and transit times are significant, whereas for road transport, the estimated elasticities for transport costs and for transit time are slightly higher than the results for Turkey.

Taking a closer look at the data, we observe that out of the 187 shipments of Spanish exports to Poland transported by sea, 150 present a cost advantage with respect to road transport whereas for the rest (37 shipments), the cost and transit time are higher by sea than by road. The question is why, then, are these shipments not transported by road? In most cases the volume of the product determines the selection of maritime transport. Out of these 37 shipments 24 correspond to vehicles and among the rest of goods there are machinery, furniture and refrigerated products.

\section{Sensitivity Analysis}

In order to evaluate the validity of the empirical results obtained in the previous section, we performed three additional tests.

First, we estimate the transport cost equation in levels (similar to Limao and Venables, 2001) in order to evaluate in monetary terms the costs of distance, service and transport conditions. We are also able to separate land and sea distances and to estimate their differential effect on transport costs. However, we only have data on land distances traveled in Spain from the city of origin to port of exit and not for port of entry to destination city. Table A.1 in the Appendix shows that the coefficient for the overland portion of the trip is much larger than sea portion. An extra $100 \mathrm{~km}$ by land adds $52 €$ per metric ton, whereas the same increase in sea distance only adds $2 €$ per metric ton. When this value is compared to the $8 €$ per metric ton predicted by the total distance from the province of origin in Spain to the destination port, we can see that using the latter measure leads to an underestimation of the effect of distance on transport costs. We also add quadratic terms to this specification, but the fit of the equation did not improve and the rest of estimated coefficients were unchanged. The extra cost of certain transport conditions is also high. The need for refrigeration increases transport costs by $29 €$ per metric ton, and a consolidated shipment is $13 €$ per metric ton more expensive than a non-consolidated one. 
Second, we separate industrial products from agricultural products and re-run similar regressions for industrial products only, for which protection is inexistent. In this way we can verify whether the trade equations may present misspecification problems when estimated for total trade, since artificial trade barriers were not included as explanatory variables and still remain to be considered for agricultural Spanish exports to Turkey. The new results indicate that the goodness of fit of the trade equations in terms of the $\mathrm{R}^{2}$ improves by 15 percentage points and that maritime transport costs are always significant for the whole sample and for exports to Poland. The signs and magnitudes of the other estimated coefficients remain almost unchanged. Table A.2 shows the regression results for the whole sample and is comparable to Table 3. Similar regressions were run for different subsamples; the results obtained validate the evidence presented above.

Finally, in order to account for the possible endogeneity of the transportation mode variable, we estimated a logit model taking the mode choice as the dependent variable and using costs and transit time differentials as the main explanatory variables ${ }^{8}$. Then, we estimated the predicted probabilities for mode choice, and this variable was incorporated into the estimations shown in Section 4 above (instead of the transportation mode dummy). The preliminary results showed that the trade elasticities, with respect to costs and transit times, were slightly lower. However, more research is needed to address this issue more carefully, and it remains outside the scope of the present study.

\section{Conclusions}

In this paper, the determinants of maritime and road transport costs were investigated and their influence on international trade evaluated. The empirical analysis was based on data from a unique data set constructed from primary sources and containing detailed information on individual shipments, transport conditions, transportation costs, transit times, real distances, modes of transport, and quality of services.

Separate analyses were made for each transportation mode. We found that for maritime transport, the main determinants are the quality of the service and the transport conditions, whereas for road transport, the main determinants are transport conditions but also real distance and transit time. Economies of scale also reduce transport costs to a greater extent in the case of road transport.

Our evaluation of the influence of transportation costs on trade has produced results indicating that road and maritime transportation costs are important determinants of trade flows.

\footnotetext{
${ }^{8}$ The results are available upon request.
} 
Addressing the title of the paper: Is distance a good proxy for transport costs? .the answer is no. If anything, distance is a better proxy for road transport costs than for maritime transport costs. On average, road transport costs have a higher influence on Spanish exports than maritime transport costs for both destinations. However, a deeper analysis reveals significant differences depending on the destination country. For Spanish exports to Poland the elasticity of exports with respect to transport costs is slightly higher for road than for maritime transport, whereas the transit time coefficient is three times higher for maritime transport than for road transport.

For Spanish exports to Turkey, transport costs are significant for both modes, with a higher coefficient for maritime transport, whereas transit time is only significant for road transport. We conclude that transit time is a more important determinant of trade for the transportation mode less commonly used for each destination country, whereas transport costs play a more important role as a determinant of exports for the transport mode more frequently used in each case.

What is clear from the results presented in this paper is that freight costs and transit time act as severe deterrents to trade. The conclusion is that policy measures for the reduction of freight rates should be pursued at the national level and by the European Union as well. At the national level, policies could be enacted deregulating transportation, increasing port capacities, and promoting those logistics industries that could in turn facilitate a reduction in transit time, speed up documentation procedures and introduce advanced information technologies. These policies could also be implemented to favor a specific transport mode. Since road congestion has become a severe problem throughout Europe, policies supporting the reduction of time and freight costs in maritime transport would contribute to an increased use of this mode and would also promote international trade.

Finally, as mentioned above, our findings indicate that the choice of transport mode also depends on cost and time conditions. Therefore, a deeper analysis of the determinants of mode choice is needed to help disentangle the relevance of each factor in explaining trade flows. This issue is left for further research. 
Table 1. Structure of Shipments for Spanish Exports to Poland and Turkey

\begin{tabular}{|c|c|c|c|c|c|c|c|c|c|c|c|c|c|c|}
\hline Destinations: & & & & Poland & & & & & & & Turkey & & & \\
\hline $\begin{array}{l}\text { Transport } \\
\text { Mode: }\end{array}$ & NS & $\begin{array}{l}\text { NS } \\
\%\end{array}$ & $\begin{array}{l}\text { TC } \\
€ / \text { ton }\end{array}$ & $\begin{array}{l}\text { TC } \\
\text { Ad-val }\end{array}$ & $\begin{array}{l}\text { Dij } \\
\text { Km }\end{array}$ & $\begin{array}{l}\text { UVI } \\
€ / \mathbf{K g}\end{array}$ & $\begin{array}{l}\text { Time } \\
\text { Days }\end{array}$ & NS & $\begin{array}{c}\text { NS } \\
\%\end{array}$ & $\begin{array}{c}\text { TC } \\
€ / \text { ton }\end{array}$ & $\begin{array}{c}\text { TC } \\
\text { Ad- } \\
\text { val }\end{array}$ & $\begin{array}{l}\text { Dij } \\
\text { Km }\end{array}$ & $\begin{array}{c}\text { UVI } \\
€ / \mathbf{K g}\end{array}$ & $\begin{array}{l}\text { Time } \\
\text { Days }\end{array}$ \\
\hline Road & 4480 & $96 \%$ & 130 & $12.06 \%$ & 2592 & 6.73 & 4.67 & 1663 & $44 \%$ & 167 & $8.85 \%$ & 3203 & 11.69 & 6.51 \\
\hline Sea & 187 & $4 \%$ & 99 & $10.67 \%$ & 6349 & 3.61 & 16.57 & 2095 & $56 \%$ & 79 & $4.47 \%$ & 4241 & 4.74 & 14.16 \\
\hline $\begin{array}{l}\text { Total/ } \\
\text { average }\end{array}$ & 4667 & $100 \%$ & 114.5 & 11.34 & 4328 & 6.6 & - & 3758 & $100 \%$ & 128 & 6.56 & 3021 & 7.8 & - \\
\hline
\end{tabular}

Notes: NS denotes number of shipments, TC denotes average transport costs in, Dij denotes real distance from the province of exit in Spain in $\mathrm{km}$ and UVI denote the average unit value index in $€ / \mathrm{kg}$. Source: TradeTrans Spanish Trade and Transport Flows, developed by Fundación Valenciaport and the authors. 
Table 2. Determinants of Maritime and Road Transport Costs (OLS)

\begin{tabular}{|c|c|c|c|c|c|c|c|c|}
\hline \multirow{2}{*}{$\begin{array}{l}\text { Dependent } \\
\text { variable: unitary } \\
\text { transport cost } \\
\text { Independent } \\
\text { variables: }\end{array}$} & \multicolumn{4}{|c|}{ Maritime Transport } & \multicolumn{4}{|c|}{ Road Transport } \\
\hline & Model 1 & Model 2 & Model 3 & Model 4 & Model 5 & Model 6 & Model 7 & Model 8 \\
\hline Constant term & $\begin{array}{c}14.26 * * \\
(4.00)\end{array}$ & $\begin{array}{c}26.87 * * * \\
(8.28)\end{array}$ & $\begin{array}{l}4.75 * * * \\
(179.49)\end{array}$ & $\begin{array}{l}4.82 * * * \\
(108.10)\end{array}$ & $\begin{array}{l}-2.95 * * * \\
(-14.85)\end{array}$ & $\begin{array}{c}-20.49 * * * \\
(-2.76)\end{array}$ & $\begin{array}{c}-4.46 \\
(-0.95)\end{array}$ & $\begin{array}{c}-2.94 \\
(-20.59)\end{array}$ \\
\hline Country dummy & $\begin{array}{l}-0.21 * * * \\
(-27.47)\end{array}$ & $\begin{array}{c}-0.21 * * * \\
(-28.26)\end{array}$ & $\begin{array}{c}-0.10 * * \\
(-7.87)\end{array}$ & $\begin{array}{c}-0.09 * * \\
(-6.25)\end{array}$ & $\begin{array}{l}0.02 * * * \\
(3.44)\end{array}$ & $\begin{array}{c}0.02 * * * \\
(3.29)\end{array}$ & $\begin{array}{c}0.063 * * * \\
(12.68)\end{array}$ & $\begin{array}{c}0.045^{* * * *} \\
(8.70)\end{array}$ \\
\hline Unit value & $\begin{array}{c}0.012 * * * \\
(5.28)\end{array}$ & $\begin{array}{l}0.012 * * * \\
(5.25)\end{array}$ & $\begin{array}{c}0.042 * * * \\
(18.20)\end{array}$ & $\begin{array}{c}0.022 * * * \\
(10.17)\end{array}$ & $\begin{array}{l}0.02 * * * \\
(9.20)\end{array}$ & $\begin{array}{c}0.02 * * * \\
(9.30)\end{array}$ & $\begin{array}{c}0.02 * * * \\
(15.16)\end{array}$ & $\begin{array}{c}0.026 * * * \\
(19.12)\end{array}$ \\
\hline Volume exported & $\begin{array}{l}-0.03 * * * \\
(-11.24)\end{array}$ & $\begin{array}{c}-0.03 * * * \\
(-21.26)\end{array}$ & $\begin{array}{c}-0.02 * * * \\
(-8.29)\end{array}$ & $\begin{array}{l}-0.02 * * * \\
(-11.27)\end{array}$ & $\begin{array}{l}-0.08 * * \\
(-61.98)\end{array}$ & $\begin{array}{l}-0.08 * * \\
(-61.97)\end{array}$ & $\begin{array}{l}0.005 * * * \\
(3.88)\end{array}$ & $\begin{array}{c}-0.009 * * * \\
(-7.795)\end{array}$ \\
\hline Real distance & $\begin{array}{c}0.066^{* * * *} \\
(5.23)\end{array}$ & $(2-10)$ & ( 8 . & (1) & $\begin{array}{l}1.09 * * * \\
(43.37)\end{array}$ & $\begin{array}{c}5.49 * * * \\
(2.95)\end{array}$ & $\begin{array}{c}1.25 \\
(1.06)\end{array}$ & $\begin{array}{l}0.94 * * * \\
(48.80)\end{array}$ \\
\hline $\begin{array}{l}\text { Squared real } \\
\text { distance }\end{array}$ & - & - & - & - & - & $\begin{array}{c}-0.27 * * * \\
(-2.36)\end{array}$ & $\begin{array}{l}-0.015 \\
-0.21)\end{array}$ & - \\
\hline Land distance & & $\begin{array}{c}0.093 * * * \\
(58.83)\end{array}$ & $\begin{array}{l}0.09 * * * \\
(62.34)\end{array}$ & $\begin{array}{c}0.09 * * * \\
(62.34)\end{array}$ & & & & \\
\hline $\begin{array}{l}\text { Port to port } \\
\text { distance }\end{array}$ & & $\begin{array}{c}0.064 * * * \\
(5.57)\end{array}$ & (2) & - & & & & \\
\hline $\begin{array}{l}\text { Dummy } \\
\text { consolidated } \\
\text { cargo }\end{array}$ & - & - & $\begin{array}{c}0.09 * * * \\
(11.41)\end{array}$ & $\begin{array}{c}0.09 * * * \\
(11.51)\end{array}$ & - & - & $\begin{array}{l}0.50 * * * \\
(103.10)\end{array}$ & - \\
\hline $\begin{array}{l}\text { Containerized } \\
\text { cargo }\end{array}$ & & & $\begin{array}{c}-0.001 * * * \\
(-7.45)\end{array}$ & $\begin{array}{c}-0.001 * * * \\
(-7.45)\end{array}$ & & & & \\
\hline $\begin{array}{l}\text { Transportation } \\
\text { mode }\end{array}$ & - & - & $\begin{array}{c}0.031 * * * \\
(4.96)\end{array}$ & $\begin{array}{l}0.035^{* * * *} \\
(4.86)\end{array}$ & - & - & - & - \\
\hline Number of lines & - & - & $\begin{array}{c}-0.09 * * * \\
(-15.16)\end{array}$ & $\begin{array}{l}-0.11 * * * \\
(-13.16)\end{array}$ & - & - & - & - \\
\hline $\begin{array}{l}\text { Dummy } \\
\text { refrigerated } \\
\text { cargo }\end{array}$ & - & - & $\begin{array}{l}0.31 * * * \\
(31.81)\end{array}$ & $\begin{array}{c}0.33 * * * \\
(30.94)\end{array}$ & - & - & $\begin{array}{c}0.38 * * * \\
(50.87)\end{array}$ & $\begin{array}{c}0.387 * * * \\
(49.77)\end{array}$ \\
\hline $\begin{array}{l}\text { cargo } \\
\text { Interaction } \\
\text { variable: } \\
\text { volume exported }{ }^{*} \\
\text { consolidation }\end{array}$ & - & - & - & 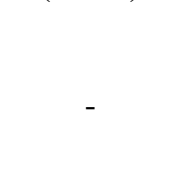 & - & - & (2) & $\begin{array}{l}0.05 * * * \\
(67.40)\end{array}$ \\
\hline $\begin{array}{l}\text { Number of days } \\
\text { between service } \\
\text { departures (freq) }\end{array}$ & - & - & $\begin{array}{c}-0.058 * * * \\
(-2.45)\end{array}$ & $\begin{array}{l}-0.029 * * * \\
(-2.03)\end{array}$ & - & - & - & - \\
\hline Number of scales & - & - & $\begin{array}{c}-0.070 * * \\
(-1.99)\end{array}$ & - & - & - & - & - \\
\hline Real transit time & - & - & - & $\begin{array}{l}0.01 * * \\
(1.97)\end{array}$ & - & - & - & $\begin{array}{l}0.098 * * * \\
(6.84)\end{array}$ \\
\hline $\begin{array}{l}\text { Adjusted R } \\
\text { squared }\end{array}$ & 0.247 & 0.470 & 0.571 & 0.551 & 0.52 & 0.52 & 0.81 & 0.802 \\
\hline $\begin{array}{l}\text { Standard error of } \\
\text { regression }\end{array}$ & 0.241 & 0.241 & 0.221 & 0.222 & 0.219 & 0.219 & 0.138 & 0.140 \\
\hline $\begin{array}{l}\text { Number of } \\
\text { observations }\end{array}$ & 8425 & 8425 & 8425 & 8425 & 8425 & 8425 & 8425 & 8425 \\
\hline $\begin{array}{l}\text { Ramsey } \\
\text { specification tests }\end{array}$ & - & - & $\begin{array}{l}\mathrm{F}(3,8410) \\
=\quad 9.40\end{array}$ & $\begin{array}{l}F(3,8410) \\
=\quad 10.45\end{array}$ & - & - & $\begin{array}{c}F(3, \\
8415)= \\
7.70\end{array}$ & $\begin{array}{l}F(3,8414) \\
=\quad 3.00\end{array}$ \\
\hline
\end{tabular}

Note: All the variables except dummies are in natural logarithms. The country dummy takes the value one when the shipments are sent to Turkey and zero when they are sent to Poland. The dummy transportation mode takes the value one when shipments are transported by road and zero when transported by sea. 
Table 3. Trade equation results (OLS)

\begin{tabular}{|c|c|c|c|c|c|c|}
\hline $\begin{array}{c}\text { Dependent variable: trade volumes } \\
\text { Independent variables: }\end{array}$ & Model 1 & Model 2 & Model 3 & Model 4 & Model 5 & $\begin{array}{c}\text { Standardised } \\
\text { B coefficients } \\
\text { (Model 5) }\end{array}$ \\
\hline Constant term & $\begin{array}{l}28.48^{* * * *} \\
(80.82)\end{array}$ & $\begin{array}{l}28.03 * * * \\
(80.69)\end{array}$ & $\begin{array}{c}27.38 * * * \\
(33.66)\end{array}$ & $\begin{array}{l}27.76^{* * *} \\
(33.12)\end{array}$ & $\begin{array}{l}25.92 * * * \\
(69.07)\end{array}$ & - \\
\hline Country dummy & $\begin{array}{l}0.83^{* * *} \\
(18.80)\end{array}$ & $\begin{array}{c}0.41 * * * \\
(8.26)\end{array}$ & $\begin{array}{c}0.44 * * * \\
(7.73)\end{array}$ & $\begin{array}{c}0.44 * * * \\
(7.77)\end{array}$ & $\begin{array}{l}1.2637 * * * \\
(22.82)\end{array}$ & 0.327 \\
\hline Maritime transport costs & $\begin{array}{l}-0.38 * * * \\
(-5.13)\end{array}$ & $\begin{array}{c}-0.25 * * * \\
(-3.43)\end{array}$ & $\begin{array}{c}-0.257 * * * \\
(-3.21)\end{array}$ & $\begin{array}{c}-0.015^{* *} \\
(-0.20)\end{array}$ & $\begin{array}{l}-0.025 \\
(-0.33)\end{array}$ & -0.00312 \\
\hline Road transport costs & $\begin{array}{l}-3.55 * * * \\
(-55.61)\end{array}$ & $\begin{array}{l}-3.43 * * * \\
(-54.17)\end{array}$ & $\begin{array}{l}-3.42 * * * \\
(-58.15)\end{array}$ & $\begin{array}{l}-1.70 * * * \\
(-19.23)\end{array}$ & $\begin{array}{l}-1.69 * * * \\
(-19.23)\end{array}$ & -0.281 \\
\hline Transportation mode & - & $\begin{array}{l}-0.81 * * \\
(-17.09)\end{array}$ & $\begin{array}{l}-0.82 * * * \\
(-17.05)\end{array}$ & $\begin{array}{l}-0.65 * * \\
(-15.38)\end{array}$ & $\begin{array}{l}-0.68 * * * \\
(-15.23)\end{array}$ & -0.158 \\
\hline Real distance sea & & & $\begin{array}{l}0.106 \\
(1.23)\end{array}$ & & & - \\
\hline Real distance road & - & - & - & $\begin{array}{c}-0.300 * * * \\
(-2.97)\end{array}$ & - & - \\
\hline Maritime transit time & - & - & - & - & $\begin{array}{c}0.121 * * \\
(2.11)\end{array}$ & 0.018 \\
\hline Road transit time & - & - & - & - & $\begin{array}{c}-3.582 * * * \\
(-28.25)\end{array}$ & -0.479 \\
\hline Adjusted R squared & 0.326 & 0.3493 & 0.3495 & 0.412 & 0.426 & \\
\hline Standard error of regression & 1.57 & 1.546 & 1.437 & 1.437 & 1.362 & \\
\hline Number of observations & 8425 & 8425 & 8425 & 8425 & 8425 & \\
\hline Correl. Country mode lctum & la lctuca & livu & & & & \\
\hline pais $\quad 1.0000$ & & & & & & \\
\hline mode $\quad-0.5787 \quad 1.0000$ & & & & & & \\
\hline lctuma $-0.4214 \quad 0.3681 \quad 1.0000$ & & & & & & \\
\hline $\begin{array}{llll}\text { lctuca } & 0.3677 & -0.0797 & 0.1998\end{array}$ & 1.0000 & & & & & \\
\hline $\begin{array}{lll}0.0610 & 0.1783 & 0.1392\end{array}$ & 0.2874 & 1.0000 & & & & \\
\hline$-0.7107 \quad 0.5120 \quad 0.3362$ & $-0.2714-$ & -0.0376 & .0000 & & & \\
\hline
\end{tabular}

Note: All the variables except dummies are in natural logarithms. Heteroskedasticity consistent t-values are in brackets. $* * * * *$ and $*$ denote significance at 1,5 and $10 \%$ levels respectively. The country dummy takes the value one when the shipments are sent to Turkey and zero when they are sent to Poland. The dummy transportation mode takes the value one when shipments are transported by road and zero when transported by sea. Correl is the correlation coefficient matrix. 
Table 4. Determinants of Transport Costs and Trade. System of Equations (3SLS)

\begin{tabular}{|c|c|c|c|c|}
\hline $\begin{array}{l}\text { Variables } \\
\text { Volume Exported }\end{array}$ & $\begin{array}{r}\text { Coefficients } \\
-1.815^{* * *}\end{array}$ & $\begin{array}{r}\text { t-values } \\
-28.620\end{array}$ & \multicolumn{2}{|c|}{ 95\% Conf. Interval } \\
\hline $\begin{array}{l}\text { Maritime transport costs } \\
\text { Road transport costs } \\
\text { Maritime transit time } \\
\text { Road transit time } \\
\text { Constant term }\end{array}$ & $\begin{array}{l}-1.815 * * * \\
-3.053 * * * \\
-0.218 * * * \\
-0.819 * * * \\
37.702 * * *\end{array}$ & $\begin{array}{r}-28.620 \\
-35.890 \\
-3.700 \\
-7.740 \\
81.460\end{array}$ & $\begin{array}{l}-1.937 \\
-3.222 \\
-0.333 \\
-1.027 \\
33.961\end{array}$ & $\begin{array}{l}-1.689 \\
-2.883 \\
-0.102 \\
-0.612 \\
35.411\end{array}$ \\
\hline $\begin{array}{l}\text { Road transport costs } \\
\text { Country dummy } \\
\text { Transportation mode } \\
\text { Unit value } \\
\text { Volume exported } \\
\text { Road distance } \\
\text { Interaction variable: volume } \\
\text { exported* consolidation } \\
\text { Dummy refrigerated cargo } \\
\text { Constant term }\end{array}$ & $\begin{array}{r}0.246 * * * \\
-0.016^{* * *} \\
0.013^{* * *} \\
-0.040^{* * *} \\
0.014 * \\
\\
0.048 * * * \\
0.388^{* * *} \\
4.850^{* * *}\end{array}$ & $\begin{array}{r}44.450 \\
-3.110 \\
8.050 \\
-27.180 \\
1.610 \\
74.180 \\
43.490 \\
61.330\end{array}$ & $\begin{array}{r}0.236 \\
-0.027 \\
0.010 \\
-0.043 \\
-0.003\end{array}$ & $\begin{array}{r}0.257 \\
-0.006 \\
0.016 \\
-0.037 \\
0.032\end{array}$ \\
\hline $\begin{array}{l}\text { Maritime transport costs } \\
\text { Country dummy } \\
\text { Transportation mode } \\
\text { Unit value } \\
\text { Volume exported } \\
\text { Land distance } \\
\text { Dummy consolidated cargo } \\
\text { Dummy refrigerated cargo } \\
\text { Number of lines } \\
\text { Number of scales } \\
\text { Number of days between service } \\
\text { departures (freq) } \\
\text { Containerized cargo } \\
\text { Constant term }\end{array}$ & $\begin{array}{r}-0.155^{*} * * \\
0.033 * * * \\
0.039 * * * \\
-0.035^{*} * * \\
0.089 * * * \\
0.064 * * * \\
0.284 * * * \\
-0.097 * * * \\
-0.077 * * * \\
-0.058^{*} * * \\
-0.001 * * * \\
-0.155^{*} * *\end{array}$ & $\begin{array}{r}-13.910 \\
5.590 \\
21.440 \\
-19.960 \\
62.450 \\
9.960 \\
27.310 \\
-16.540 \\
-5.630 \\
-10.180 \\
-11.430 \\
-13.910\end{array}$ & $\begin{array}{r}-0.177 \\
0.021 \\
0.035 \\
-0.039 \\
0.086 \\
0.051 \\
0.264 \\
-0.109 \\
-0.104 \\
-0.070 \\
-0.001 \\
-0.177\end{array}$ & $\begin{array}{r}-0.134 \\
0.044 \\
0.042 \\
-0.032 \\
0.092 \\
0.076 \\
0.305 \\
-0.086 \\
-0.050 \\
-0.047 \\
-0.001 \\
-0.134\end{array}$ \\
\hline $\begin{array}{l}\text { Equation } \\
\text { Volume exported } \\
\text { Road transport costs } \\
\text { Maritime transport costs }\end{array}$ & $\begin{array}{r}\text { Obs } \\
8425 \\
8425 \\
8425 \\
\end{array}$ & $\begin{array}{c}\text { RMSE } \\
1.721 \\
0.176 \\
0.186\end{array}$ & $\begin{array}{r}\text { R-sq } \\
0.194 \\
0.692 \\
0.553 \\
\end{array}$ & $\begin{array}{r}\text { chi2 } \\
5854.440 \\
23047.550 \\
12339.500\end{array}$ \\
\hline $\begin{array}{l}\text { Durbin-Wu-Hausman test } \\
\mathrm{F}(1.8418)\end{array}$ & H0:Regressor & exogenous & 687.34 & $1 * * *$ \\
\hline
\end{tabular}

Note: All the variables except dummies are in natural logarithms. Heteroskedasticity consistent t-values are in brackets. $* * *, * *$ and $*$ denote significance at 1,5 and $10 \%$ level respectively. The country dummy takes the value one when the shipments are sent to Turkey and zero when they are sent to Poland. The dummy transportation mode takes the value one when shipments are transported by road and zero when transported by sea. 
Table 5. Determinants of Transport Costs and Trade: Turkish Market (3SLS)

\begin{tabular}{|c|c|c|c|c|}
\hline \multirow[b]{2}{*}{ Variables } & \multicolumn{2}{|c|}{ Maritime Transport } & \multicolumn{2}{|c|}{ Road Transport } \\
\hline & Coefficient & t-statistic & Coefficient. & t-statistic \\
\hline \multicolumn{5}{|l|}{ Volume Exported } \\
\hline Transport costs & $-4.715 * * *$ & -22.710 & $-3.538 * * *$ & -17.790 \\
\hline Transit time & $0.180 * * *$ & 1.450 & $-0.849 * * *$ & -4.000 \\
\hline Constant term & $29.919 * * *$ & 32.520 & $28.733 * * *$ & 40.390 \\
\hline \multicolumn{5}{|l|}{ Road transport costs } \\
\hline Unit value & & & $0.015 * * *$ & 5.210 \\
\hline Volume exported & & & $-0.111 * * *$ & -30.510 \\
\hline Road distance & & & $0.735 * * *$ & 18.340 \\
\hline Interaction variable: volume exported* & & & $0.034 * * *$ & 25.540 \\
\hline consolidation & & & & \\
\hline Dummy refrigerated cargo & & & $0.290 * * *$ & 5.120 \\
\hline Constant term & & & -0.005 & -0.010 \\
\hline \multicolumn{5}{|l|}{ Maritime transport costs } \\
\hline Unit value & $0.059 * * *$ & 12.320 & & \\
\hline Volume exported & $-0.021 * * *$ & -2.340 & & \\
\hline Land distance & $0.082 * * *$ & 27.660 & & \\
\hline Dummy consolidated cargo & $0.202 * * *$ & 7.700 & & \\
\hline Dummy refrigerated cargo & $0.594 * * *$ & 6.460 & & \\
\hline Number of lines & $-0.091 * * *$ & -4.160 & & \\
\hline Number of scales & $-0.427 * * *$ & -9.810 & & \\
\hline $\begin{array}{l}\text { Number of days between service departures } \\
\text { (freq) }\end{array}$ & - & - & & \\
\hline Constant term & $4.627 * * *$ & 30.780 & & \\
\hline Number of observations & 2095 & & 1663 & \\
\hline Equation & RMSE & R-sq & RMSE & R-sq \\
\hline Volume exported & 1.998 & 0.109 & 1.106 & 0.425 \\
\hline Road transport costs & & & 0.174 & 0.659 \\
\hline Maritime transport costs & 0.194 & 0.532 & & \\
\hline
\end{tabular}

Note: All the variables except dummies are in natural logarithms. Heteroskedasticity consistent t-values are in brackets. $* * *, * *$ and $*$ denote significance at 1,5 and $10 \%$ level respectively. 
Table 6. Determinants of Transport Costs and Trade: Polish Market (3SLS)

\begin{tabular}{|c|c|c|c|c|}
\hline \multirow[b]{2}{*}{ Variables } & \multicolumn{2}{|c|}{ Maritime Transport } & \multicolumn{2}{|l|}{ Road Transport } \\
\hline & Coefficient & t-statistic & Coefficient & t-statistic \\
\hline \multicolumn{5}{|l|}{ Volume Exported } \\
\hline Transport costs & $-3.050 * * *$ & -4.620 & $-3.650 * * *$ & -25.760 \\
\hline Transit time & $-3.902 * * *$ & -4.290 & $-1.288 * * *$ & -5.970 \\
\hline Constant term & $35.066 * * *$ & 8.730 & $29.091 * * *$ & 59.340 \\
\hline \multicolumn{5}{|l|}{ Road transport costs } \\
\hline Unit value & & & $0.018 * * *$ & 10.830 \\
\hline Volume exported & & & $-0.076 * * *$ & -31.300 \\
\hline Road distance & & & $0.790 * * *$ & 43.780 \\
\hline Interaction variable: volume & & & $0.036 * * *$ & 42.050 \\
\hline exported* consolidation & & & & \\
\hline Dummy refrigerated cargo & & & $0.359 * * *$ & 47.670 \\
\hline Constant term & & & $-0.870 * * *$ & -5.950 \\
\hline \multicolumn{5}{|l|}{ Maritime transport costs } \\
\hline Unit value & $-0.095 * *$ & -2.400 & & \\
\hline Volume exported & 0.006 & 0.230 & & \\
\hline Land distance & $0.103 * * *$ & 7.890 & & \\
\hline Dummy consolidated cargo & $0.216^{* * *}$ & 2.740 & & \\
\hline Dummy refrigerated cargo & $0.331 * * *$ & 6.590 & & \\
\hline Number of lines & $-0.128 * *$ & -2.320 & & \\
\hline Number of scales & $0.140 *$ & 1.810 & & \\
\hline Number of days between service & $0.061 * *$ & 2.480 & & \\
\hline \multicolumn{5}{|l|}{ Departures (freq) } \\
\hline Constant term & 3.801 & 9.590 & & \\
\hline Number of observations & 187 & & 4480 & \\
\hline Equation & RMSE & R-sq & RMSE & R-sq \\
\hline Volume exported & 2.254 & 0.069 & 1.565 & 0.270 \\
\hline Road transport costs & & & 0.152 & 0.698 \\
\hline Maritime transport costs & 0.165 & 0.691 & & \\
\hline
\end{tabular}

Note: All the variables except dummies are in natural logarithms. Heteroskedasticity consistent t-values are in brackets. $* * * * *$ and $*$ denote significance at 1,5 and $10 \%$ level respectively. 


\section{References}

Anderson, J. E. and van Wincoop, E. (2003), "Gravity with gravitas: A solution to the border puzzle", American Economic Review, 93, 170-192.

Anderson, J. E. and van Wincoop, E. (2004), “Trade Costs”, Journal of Economic Literature, XLII, 691-751.

Bergstrand, J. H. (1985), “The gravity equation in international trade: Some microeconomic foundations and empirical evidence", The Review of Economics and Statistics, 67, 474-481.

Bergstrand, J. H. (1989), "The generalized gravity equation, monopolistic competition, and the factor-proportions theory in international trade", The Review of Economics and Statistics, 71, 143-153.

Clark, X., Dollar, D. and Micco, A. (2004), "Port efficiency, maritime transport costs, and bilateral trade", Journal of Development Economics, 75, 417-450.

Combes, P.P. and Lafourcade, M. (2005), "Transport costs: Measures, determinants and regional policy implications for France”, Journal of Economic Geography 5 (3), 319-349.

Deardorff, A. V. (1995), "Determinants of bilateral trade: Does gravity work in a Neoclassical word”, NBER Working Paper 5377.

Durbin, J., Errors in Variables, (1954), Review of the International Statistical Institute, Vol. 22, pp. 23-32.

Egger, P. (2004), "On the impact of transportation costs on trade in a multilateral world", Southern Economic Journal 71 (3), 592-606.

Feo, M., García, L., Martínez, I. and Pérez, E. (2003), "Determinants of modal choice for freight transport: consequences for the development of short sea shipping between Spain and Europe". En Maritime Transport II. Second International Conference on Maritime Transport and Maritime History. Volumen I, 767-669. SCI UPC 2003. Barcelona.

Frankel, J., Stein, E. and Wei, S. J. (1995), “Trading blocs and the Americas: the natural, the unnatural, and the super-natural", Journal of Development Economics, 47, 61-95.

Hausman, J. (1978), Specification Tests in Econometrics, Econometrica, Vol. 46, No. 6, pp. 1251-1271.

Hoffmann, J. (2001), "Latin American Ports: Results and Determinants of Private Sector Participation”, International Journal of Maritime Economics, 3, 221-241.

Hoffmann, J., Micco, A., Pizzolotti, G., Sánchez, R., Sgut, M. and Wilmsmeier, G. (2003), "Port Efficiency and International Trade: Port Efficiency as a Determinant of Maritime Transport Cost". Maritime Economics and Logistics, 5 (2).

Hummels, D. (2001), “Towards a Geography of Trade Costs” mimeo. Purdue University- 
Krugman, P. (1991). "Increasing Returns and Economic Geography”, Journal of Political Economy 99 (3), 483-499.

Limao, N. and Venables, A. J. (2001), "Infrastructure, geographical disadvantage, transport costs and trade", The World Bank Economic Review, 15 (3), 451-479.

Martínez-Zarzoso, I. and Suárez-Burguet, C. (2005), “Transport costs and trade: empirical evidence for Latin American imports from the European Union". Journal of International Trade and Economic Development, 14(3), 227-245.

Martínez-Zarzoso, I., García-Menéndez, L. and Suárez-Burguet, C. (2003), "The impact of transport costs on international trade: The case of Spanish ceramic exports", Maritime Economic and Logistics, 5, 179-198.

Martínez-Zarzoso, I., Pérez-García, E.M., Sanjuan-Lucas, M.E. y Suárez-Burguet, C. (2004), "How Important are Transport Costs for International Trade? An Empirical Study for Spanish Exporting Sectors", International Association of Maritime Economists - IAME Annual Conference 2004 Proceedings, Volumen I, Dokuz Eylul Publications, 597-608.

Micco, A. and Pérez, N. (2002), "Determinants of Maritime Transport Costs”. Inter-American Development Bank.

Radelet, S., Sachs, J. (1998), "Shipping Costs, Manufactured Exports and Economic Growth", Harvard University, Harvard Institute for International Development. Mimeographed document. Harvard, MA, USA.

Shipping World \& Shipbuilder (2003), "Ultra-large container ships: the green ships of the future".

UNCTAD (2004), Review of Maritime Transport 2004, UNCTAD, Geneva.

World Bank (2005), "Data on Trade and Import Barriers. 


\section{Appendix}

A.1. Cost of Shipments from Spain to Poland and Turkey

\begin{tabular}{|l|l|l|l|l|l|l|}
\hline $\begin{array}{l}\text { Dep. Var: transport cost } \\
(€ / \text { metric ton })\end{array}$ & $\underline{\text { Coef. }}$ & $\underline{\mathbf{t}}$ & $\underline{\text { Beta }}$ & $\underline{\text { Coef. }}$ & $\underline{\text { t }}$ & $\underline{\text { Beta }}$ \\
\hline Constant term & $70.212^{* * *}$ & 35.050 & & $70.093^{* * *}$ & 31.370 & \\
\hline Country dummy & $-15.383^{* * *}$ & -14.150 & -0.290 & $-12.896^{* * * *}$ & -11.920 & -0.243 \\
\hline Unit value & $0.045^{* * *}$ & 2.560 & 0.022 & $0.098^{* * *}$ & 5.320 & 0.049 \\
\hline Volume exported & -0.000 & -1.320 & -0.017 & -0.000 & -0.900 & -0.010 \\
\hline Dummy consolidated cargo & $13.096^{* * *}$ & 22.300 & 0.247 & $12.172^{* * *}$ & 23.350 & 0.230 \\
\hline Dummy refrigerated cargo & $34.736^{* * *}$ & 33.050 & 0.287 & $29.801^{* * *}$ & 31.510 & 0.246 \\
\hline Transportation mode & $1.605^{* *}$ & 2.110 & 0.027 & $2.762^{* * *}$ & 4.350 & 0.047 \\
\hline Distance & $0.008^{* * *}$ & 16.980 & 0.435 & - & - & - \\
\hline Sea distance & - & - & - & $0.002^{* * *}$ & 4.990 & 0.114 \\
\hline Land distance & - & - & - & $0.052^{* * *}$ & 59.760 & 0.500 \\
\hline Number of scales & -6.057 & -11.330 & -0.346 & 0.169 & 0.354 & 0.009 \\
\hline R & 0.291 & & & 0.5084 & & \\
\hline
\end{tabular}

Note: Transport costs equation in levels. Heteroskedasticity consistent t-values are in brackets. ***,**and * denote significance at 1, 5 and $10 \%$ level respectively.

A.2. Trade Equations for Industrial Products

\begin{tabular}{|c|c|c|c|c|c|}
\hline $\begin{array}{c}\text { Dependent variable: trade } \\
\text { volumes } \\
\text { Independent variables: }\end{array}$ & Model 1 & Model 2 & Model 3 & Model 4 & Model 5 \\
\hline Constant term & $\begin{array}{l}31.47 \text { *** } \\
(92.61)\end{array}$ & $\begin{array}{l}30.03 * * * \\
(80.69)\end{array}$ & $\begin{array}{l}28.38 * * * \\
(76.66)\end{array}$ & $\begin{array}{l}25.22 * * * \\
(34.04)\end{array}$ & $\begin{array}{l}24.72 * * * \\
(66.43\end{array}$ \\
\hline Country dummy & $\begin{array}{c}1.06 * * * \\
(25.77)\end{array}$ & $\begin{array}{c}0.65 * * * \\
(8.26)\end{array}$ & $\begin{array}{c}0.71 * * * \\
(15.89)\end{array}$ & $\begin{array}{c}0.71 * * * \\
(13.18)\end{array}$ & $\begin{array}{l}1.34 * * * \\
(26.38)\end{array}$ \\
\hline Maritime transport costs & $\begin{array}{c}-0.92 * * * \\
(-13.03)\end{array}$ & $\begin{array}{c}-0.78 * * * \\
(-11.25)\end{array}$ & $\begin{array}{c}-0.579 * * * \\
(-8.53)\end{array}$ & $\begin{array}{c}-0.578 * * * \\
(-8.51)\end{array}$ & $\begin{array}{c}-0.34 * * * \\
(-5.17)\end{array}$ \\
\hline Road transport costs & $\begin{array}{c}-3.73 * * * \\
(-62.67)\end{array}$ & $\begin{array}{c}-3.59 * * * \\
(-60.17)\end{array}$ & $\begin{array}{c}-3.25 * * * \\
(-55.15)\end{array}$ & $\begin{array}{c}-3.25 * * * \\
(-55.44)\end{array}$ & $\begin{array}{c}-1.89 * * * \\
(-23.43)\end{array}$ \\
\hline Transportation mode & - & $\begin{array}{l}-0.78 * * \\
(-17.69)\end{array}$ & $\begin{array}{c}-0.55 * * \\
(-9.95)\end{array}$ & $\begin{array}{l}-0.55 * * \\
(-12.48)\end{array}$ & $\begin{array}{l}-0.44 * * \\
(-10.37)\end{array}$ \\
\hline Real distance & - & - & - & $\begin{array}{l}-0.092 \\
(-0.12)\end{array}$ & - \\
\hline Maritime transit time & - & - & - & - & $\begin{array}{c}0.08 \\
(1.63)\end{array}$ \\
\hline Road transit time & - & - & - & - & $\begin{array}{c}-2.692 * * * \\
(-23.67)\end{array}$ \\
\hline Adjusted R-squared & 0.436 & 0.457 & 0.496 & 0.497 & 0.53 \\
\hline Standard error of regression & 1.47 & 1.346 & 1.337 & 1.32 & 1.262 \\
\hline Number of observations & 7365 & 7365 & 7365 & 7365 & 7365 \\
\hline
\end{tabular}

Note: Industrial products considered are included in Chapters 16 to 96 in the Harmonized System. Heteroskedasticity consistent t-values are in brackets. ***, ** and * denote significance at 1, 5 and $10 \%$ level respectively. 